\title{
Ethnic Hierarchies and the Shifting EU Schengen Border in the Post-Cold War Era
}

Lynn M. Tesser*

\begin{abstract}
Borders in Central and Eastern Europe witnessed stark changes in recent decades. Frontiers went from high security zones during the Cold War to far more open borders as socialism retreated. Yet, the subsequent eastward shift of the European Union's Schengen border control system returned some borders to high security status, with only a few later shedding such status as the system moved further eastwards. Beyond discerning how the Schengen border undercuts the EU's effort to promote non-discrimination and other liberal values, this article also shows how Schengen holds the power to further entrench perceptions of ethnic hierarchy.
\end{abstract}

Keywords: Central Europe, Eastern Europe, Borders, Schengen, EU Enlargement, Nationalism, National Identity, Liberalism

\footnotetext{
${ }^{*}$ Corresponding author: Dr. Lynn M. Tesser, Independent Researcher
} 


\section{Introduction}

During the socialist era, borders across Central and Eastern Europe (CEE) tended to be high security zones with minimal cross border traffic. It was a stark contrast to communist elites' professed 'friendship' between socialist countries. Such strict controls did little to further amicable relations among those separated by borders. When no longer subject to the contradiction between the 'socialist brotherhood' rhetoric of the communist era coinciding with intensive border policing, newfound freedom of movement catalyzed many incidents of intolerance. Visa-free travel nevertheless soon allowed border residents to see that their fears about each other were overblown and, more importantly, to get accustomed to ethnic intermingling as a regular, everyday occurrence.

After five years of relative openness, several borders in East-Central Europe such as the Polish-German and Czech-German borders were once again subject to substantial increases in policing with the eastward movement of the EU's outer Schengen frontier. Established towards the end of the Cold War, 'Schengen' refers to the EU's well-fortified outer border control system largely designed to soothe West European fears of sizeable population movements from the east and south. Formally speaking, it is an intergovernmental convention among consenting EU member states that lays down common rules for customs, visa, asylum, police, and border control. The construction of this 'hard' outer frontier has not only been a key part of Western Europe's post-cold war security policy, it has also been instrumental for promoting free movement within 'Schengenland' and the idea of creating a 'Europe of the regions.'

In April 1998, the Austrian-Hungarian, Austrian-Czech, and ItalianSlovenian borders also became hard borders after earlier Schengen signatories judged Austria and Italy fit to conduct the required policing at least until the Czech Republic, Hungary and Slovenia themselves joined Schengenland in 2007. Taking the Polish-German border as an example, evidence of heightened policing comes from the fact that the number of German personal working in border control and funding allotted for this task went from 24,982 and DM 1.3 million $(\$ 650,000)$ in 1989 to 40,100 and DM 2.9 million (\$ 1.45 million) in 1997 (Bort 1999: 84).

Yet, the Schengen system holds the drawbacks for promoting the liberal values central to EU non-discrimination policy for at least two reasons: 
(1) CEE countries have had to adopt the system while several older EU member states have the right to opt out, and (2) Schengen ironically replicates in a way the illiberal Soviet-era border regime (though not within the Single Market itself). The EU, in fact, only finally established the 'Wider Europe' initiative in March 2003 to deal more systematically with its new neighbors. Rather diplomatically problematic, however, was the document's tendency to associate the western CIS with the Middle East and North Africa (Ukraine, Poland 2003: 1), an idea congruent with what Wojciech Sadurski has called the veritable return of the menacing 'Tartar hordes' in the European popular imagination (Sadurski 2002: A9).

Beyond replicating some Soviet border control practices, the lack of flexibility in regard to incoming states - particularly when the EU offered present members flexible options - does not breed respect for liberal values and suggests a second class status for new and incoming states. That the EU allows the UK, Ireland, and Denmark to be partially outside the Schengen system (and non-members such as Iceland and Norway to be partially in) signals a stark difference in treatment. Prior to Poland's joining the Schengen zone, Wojciech Sadurski reflected on the situation in Rzeczpospolita:

In the past, new member states had easier demands: the Schengen system was not as rigorously tied to the conditions of membership. For example, in spite of Italy and Greece's membership in the EU these countries had to wait seven years to be accepted to Schengen because for that long the other signatories did not truly trust in their ability to defend the borders. In our case - without certain border security (according to EU criteria) there would not be talk of joining the club.

A great asymmetry rules relations between the EU and us that we have to realize and that is particularly apparent in relation to borders and immigration.

Everything indicates that the EU precedes with seriousness and distrust to our - and in the future their - borders. The costs to the candidate countries will be high. We pay the price of unavoidable decline of border trade while the Hungarians' require exit visas for Hungarians living in Romania (Sadurski 2002: A9).

Border trade is key in economically depressed border regions with borders serving as both markers and reinforcers of economic difference. 
Hungary faces the rather unique situation of Schengen dividing the country from sizeable Hungarian minorities in Romania and in Serbia's Vojvodina - until at least Romania joins the Schengen system.

This article concentrates on Poland and Hungary as these countries had to make sizeable preparations on their borders for the shifting Schengen system. It has several aims: (1) to show why Schengen fits rather awkwardly in post-Cold War CEE, namely because it was a product of another time and place; (2) to demonstrate that Schengen's implementation only furthered ethnic hierarchies - in earlier times at the Czech-German and Polish-German borders and still at the HungarianRomanian and Polish-Ukrainian borders; and finally (3) to show that Schengen's inadvertent reinforcement of the idea of creating a 'Europe of the regions' suggests a changing balance of power among Europe's less historically secure nationalities that can appear threatening. In fact, the position of Hungary - with the main Hungarian center-right party using EU expansion as a means to reunify the Hungarian nation - could become especially problematic if interpreted as a security concern for Romania and Slovakia. European integration can amplify what Zsuzsa Csergő and James Goldgeier have labeled 'transsovereign nationalism' (Csergő and Goldgeier 2004: 26) - a form of nationalist politics in which a national centers (such as Budapest) develop specific institutions and policies that reinforce and even increase the sense of shared nationhood linking the state (Hungary) with kin next door (Hungarians in Romania, Slovakia, etc.).

History explains why the idea of creating a 'Europe of the regions' can mean something different in CEE. While border regions here generally tend to have poorly developed infrastructure and industry as well as lower concentrations of population - like in Western Europe, unique to the region are the lingering effects of border shifts as well as population expulsions and transfers based on ethnicity during and after the Second World War. Not only have societies and elites not come to terms with the expulsions and related movements, but the settlers who replaced those departing to often have weaker ties to their new localities - making them more susceptible to negative stereotypes concerning people living on the other side of the border. Such a historical experience ultimately makes border regions a bit different than most of their counterparts in the earlier EU-15 wherein there is a greater degree of knowledge of those living on the other side, ethnic-intermingling, and far fewer recent boundary 
changes - though certainly sharing a tendency to be underdeveloped with respect to the center.

\section{The Creation of the Schengen Border System}

Emerging in the second half of the 1980s, Schengen was an effort to make good on the goals established at Rome in 1957 and reiterated in the 1985 Single European Act - that is, to bring down borders for the free movement of EU nationals, allowing them to work and live anywhere in the Union. Signed initially by France, Germany, and the Benelux countries, the First Schengen Agreement on the Gradual Abolition of Checks at the Common Borders from July 1985 aimed to remove controls on movement as quickly as possible, while stopping well short of articulating a general European policy on immigration and asylum. This agreement had two ultimate goals: (1) to harmonize signatories' visa regulations, and in certain cases, policies concerning aliens' law; and (2) to test the waters for the application of such a border control system along other internal borders (Lavenex 1999: 36).

Prior to extending invitations to other states, however, these same five mavericks furthered their commitment towards border control harmonization by agreeing to extensive regulations concerning immigration and asylum in the 1990 Second Schengen Agreement. Formulated largely by national interior ministry representatives preoccupied with internal security (i.e. issues of immigration and crime), the second agreement was a key step in harmonizing this ambitious border control regime by establishing guidelines for dealing with citizens of non-member states categorized as 'third country nationals.' Designed to handle the steep increase in population flows from the East, this second agreement maintains that a Schengen signatory may refuse to consider an asylum claim made by a third state national if s/he traveled previously through a 'safe third country' - a non-member state signatories deem safe for refugees - to reach the desired country of destination. Given that many intending to claim asylum in EU-15 countries travel through CEE prior to reaching Western Europe, being categorized as a 'safe third country' inadvertently drew CEE states into the emerging European refugee policy beginning in the early 1990s (Lavenex 1999: 51).

Despite sharp disagreement over harmonizing such policies, most EU member states had, in fact, joined the Schengen system by the mid- 
1990's. After a 5-year preparatory period following German reunification, Schengen controls finally came into force for France, Germany, the Benelux countries, Spain, and Portugal in March 1995. Not long thereafter Schengen became part of the EU's framework following the signing of the Amsterdam Treaty, with special arrangements made for Denmark, the UK, and Ireland (and Norway and Iceland that are not EU member states). Austria and Italy joined in 1997, Greece in 2000, before Sweden, Denmark, Finland, Iceland and Norway in 2001. The year 2007 then brought in nine additional countries: Poland, the Czech Republic, Slovakia, Slovenia, Hungary, Latvia, Lithuania, Estonia, and Malta.

Interestingly enough, Schengen continues to be marked more by its Cold War era birth than by the post-Cold War period when it came into force. The initial steps for launching a fully liberalized internal market came, first, when the Cold War provided a clear limit to the EU's potential geographical domain, not to mention security-oriented reasons to construct an integrated economic bulwark. Even more than a decade after 1989, it is indeed easy to forget how the division of Europe into East and West facilitated European economic integration by providing a seemingly natural limit on the number of countries that could be included. The continuing formidableness of the Soviet Union too facilitated cooperation by providing a shared threat.

The idea of allowing free movement had also been around since the 1957 Treaty of Rome created the Common Market and allowed the free movement of workers across EC member states' borders - though excluding migrant workers from ex-colonies, north Africa, and Eastern Europe. The second part of the equation then lies in the economic liberalization developing since the end of Second World War and coming into full swing in the 1980 's; in combination with a more restrictive attitude towards accepting refugees in Western Europe commencing in the 1970's. The first key move in the direction of liberalizing capital flows came when the OECD drew up the Code of Liberalization of Capital Movements in 1961 to end restrictions among member states "to the extent necessary for effective economic cooperation" (Goodman and Pauly 1993: 51-53). Yet, in view of payment imbalances and rigid exchange rates, however, governments of nearly all industrial countries continued to exercise some control over capital flows during the 1960's (Goodman and Pauly 1993: 51-53). Even the demise of the Bretton 
Woods system of exchange rates in the early 1970's did not signal deregulation.

Concerning population flows, on the other hand, West European asylum and immigration policies were comparatively liberal during this same time. Governments were anything but against East $\rightarrow$ West migration as this trend appeared proof positive of capitalist democracy's superiority. It was only with the refugee flows accompanying postcolonial conflicts that led to a progressive tightening of immigration and asylum policies.

While this was occurring in the 1970's, capital markets were beginning to loosen and the free flow of West European labor across borders gained greater importance. Two catalysts were key in the liberalization of investment flows: first, the steep growth of international financial markets (combined with technological changes that quickened the transfer process); and second, the fact that more businesses began to think in terms of arranging production globally (Goodman and Pauly 1993: 51-53). Along with other benefits FDI can bring, the desire to avoid capital controls was indeed an important part of this latter trend. When controls in a particular country became comparatively high, for example, firms situated therein could execute their exit option without closing shop by simply shifting some operations to subsidiaries in countries with fewer regulations (Goodman and Pauly 1993: 58). Governments subsequently came to the realization that instituting restrictions thought to decrease predicted return would lead to capital flight, and with it, jobs and part of the tax base Scharpf 1999: 39). International events such as the GATT and WTO negotiations also furthered this trend by supporting reductions in tariffs and restrictions on quantities of particular imports, not to mention supporting the replication of British- and U.S.-based privatization and deregulation (Scharpf 1999: 39). With the added incentive of competing against U.S. economic power, the EU facilitated liberalization through creating the internal market and, given the more restrictive attitude towards refugees and other immigrants, the emphasis on creating geographical limits to it.

The first serious mention of allowing greater liberalization of human movement within particular geographic limits came within the summary of the EC's 1974 Paris Conference stating that working groups would be established to help create a passport union for member states. The main issue that hindered the development of the union was the difficulty of 
differentiating between EC nationals and citizens of third countries, particularly since states would not give up any of their ability to make sovereign decisions on immigration and asylum policy without great reluctance. While the European Commission began to work on the creation of a European passport, the inflow of asylum seekers after the late 1970's did not help increase interest in the idea of harmonization. Later, the Commission reacted by toning down its emphasis on removing all controls to simply make cross border movement easier (Taschner 1997: 16). In the end, it was only through a slow step-by-step process that the idea of harmonizing policies towards third countries gained a modicum of acceptance (outlined in Taschner 1997).

Given that the 1997 Amsterdam Treaty made the Schengen system a part of the EU's framework, all CEE applicant countries subsequently commencing their negotiation processes with the EU would have no choice but to accept it. Given some member states' hypersensitivity concerning increased crime and unemployment spurred by immigration from the East, the EU has demanded that incoming states demonstrate their readiness to police these borders by implementing reforms prior to formal entry. It is in this way that the EU uses the Schengen system along with its sizeable leverage to provide a second line of defense against unwanted immigration - yet a policy that does not have strong social support in these incoming states. Hungarian elites and society hardly wish to cut off ties with Hungarians in the near abroad, while their counterparts in Poland consider more open borders necessary for stability next door to the east.

Understanding the particular conditions within which Schengen arose signals how much it was a product of its time - the economic liberalization wave gaining speed in the beginning of the 1980's, the desire to revive the goals of Rome, and caution towards accepting asylum seekers and immigrants during the Cold War. Though CEE too confronts increased economic liberalization, these countries were not involved in the shaping of the Single Market, nor do they wish to construct hard borders with their neighbors to the East. Requiring the adoption of the Schengen border ultimately runs against liberal principles that the EU and other international organizations desire to cultivate in CEE - yet, within the contemporary context, appear politically crucial for elites in a number of older EU member states concerned about population movements from the East. 


\section{Schengen and the Reconstruction of Ethnic Hierarchies}

Ethnic hierarchies in Europe certainly pre-dated Schengen. Yet, the construction of a hard border delineating 'Europe' from 'not-Europe' (or 'not-fully-Europe') furthers the sense of civilizational superiority inside the Schengen group and inferiority outside of it. This was certainly true in the case of the Polish-German border - until recently, the longest frontier on the EU's outer eastern boundary. Given its greater length, strict north-south direction, and particular geopolitical location, the Polish-German border took on particular importance as symbolic divider between 'East' and 'West' after German reunification. Polish sociologist Zbiegniew Kurcz points out the irony of this symbolism.

After October 1990, the Polish-German border became simultaneously the eastern border of the EU and NATO. What is equally important is that in the social consciousness of millions of Poles and of our eastern neighbors the Polish-German border became the border of two worlds. The first is identified with well-being, increases in economic development, democracy, and consumption, whereas the second, to an equally natural degree, with deficiency and social problems resulting from the departure of a planned economy that until recently exercised near total control. It is of course possible to provide evidence that elements of a market economy and of citizen freedoms existed more in Poland than in East Germany in earlier years. That, however, does not change the fact that in a relatively short time the East Germans accepted the values, aims, and standards practiced in the FRD - what, though, only recently confirms the civilizational and cultural function of the PolishGerman border as the border between Eastern and Western Europe (Kurcz 1992: 2).

Kurcz rightly points to the importance of associations frequently made between nationality and the level of material culture, leading nationalities associated with richer states to be accorded greater esteem and more positive qualities. Such asymmetries matter a great deal for issues of nationality because a higher standard of living automatically builds respect and diminishes the resonance of prejudice. One need only contrast Poles' respect for Germans despite strong memories of German domination and Germans' more negative attitudes towards Poles, not to mention Ukrainians' greater respect for Poles than vice versa. Without a doubt, the substantial material inequalities between Poland and Germany - and later, the shift of Schengen to this border - helped to make this the 
preeminent East-West divide. This division was indeed far more natural than the German-German border of the communist era - a construction that is already reproducing itself now that the EU's outer border has shifted to Poland's border with Ukraine and Belarus.

Compared to their counterparts in other CEE states now within the EU, Polish and Hungarian elites place the highest value on maintaining a relatively open border with neighbors to the East - meaning that ideally no visas should be required for entry from citizens from neighboring states. Polish elites have taken such a border, particularly with Ukraine, to be crucial for stability in the region while Hungarian elites resist making entry difficult for the large number of Hungarians in the near abroad. For Poland, making Ukrainians in particular face these controls not only contradicts earlier assurances of openness, but impedes any genuine form of Polish-Ukrainian reconciliation over Second World War ethnic cleansing and the possibility of overcoming another great economic divide in Europe. Even as late as 1998, in fact, Polish politicians promised their Ukrainian counterparts that the PolishUkrainian border will be "just as open as it always was" after Poland's EU entry (Pawlicki 2002: 12). This was contradicted not long afterward when the Polish government accepted a resolution signaling that visas would be demanded of Belorussians and Russians - with Ukrainians requiring them only the moment Poland joined the EU (Pawlicki 2002: 12). While the Buzek government agreed to have the controls operative in 2001, the succeeding Miller government pushed the date to 1 July 2003 - for the introduction of visas for Russians, Belorussians, and Ukrainians (Pawlicki 2002: 12).

The first explicit signal concerning visa requirements came from the EU's 1998 "Partnership for Membership." This document mandated visas for Belorussians, Russians, and Ukrainians as one of the policy changes for the Polish government to undertake (Bielecki 1998a: 9). The promotion of visas, in fact, just happened to follow on the heels of a 1997 law on foreigners that tightened the eastern border. Coming into force in December 1997, this legislation required Belorussians and Russians entering Poland to have their vouchers validated beforehand either by a government official or a notary confirming possession of enough funds to cover their stay. The appropriate vouchers could no longer be cheaply bought at a bazaar and rose in cost from $\$ 1$ to $\$ 20$ (Gęstsze sito 1998: 3). While the introduction of the 1997 law was often taken to be due to EU 
pressure, it would have eventually been undertaken to bring the practice of border control into line with preexisting domestic legislation (Bachmann 2000: A9). Nevertheless, implementing the law signaled clear intent to increase controls along this border when it was becoming increasingly important to be taken seriously by the EU. Financial compensation came in the form of an EU-funded program to modernize the Polish eastern border with Poland receiving $€ 15$ million (\$ 17 million) in 1998 (Bielecki 1998b: 3).

At least two significant things resulted from the 1997 law's coming into force. First, sales at bazaars on the Polish side dropped significantly bazaars being a key source of income and employment in economically depressed border areas, particularly those with some degree of economic asymmetry. 1999 figures indeed show that sales were only $41 \%$ of what they had been in 1996. Second, a local (to the eastern border area) and national debate took place over the legitimacy of the controls and of the necessity of the bazaars in Poland. However, it is difficult to be certain what the general view on the control of the eastern border is as opinion surveys from 1994 and 1998 show that respondents tended not to embrace 'free movement' (swobodny ruch) across the eastern border. Respondents' views concerning a fully open border (meaning no controls) cannot simply be assumed to hold for their views on a relatively open border - like the one that has existed since the end of the Cold War up until the application of the Schengen system. The highest percentage in both years, in fact, agreed with the view that an open border would not be overwhelmingly beneficial. 56\% in 1994 and 44\% in 1998 said that freedom of movement across the border for Polish citizens and nationals of the former Soviet Union brings more harm than good. 24\% in 1994 and $28 \%$ in 1998 said that such freedom would bring as much good as bad, while $7 \%$ and later $17 \%$ thought that it brings more good than bad. Most noteworthy in this survey, however, is the positive trend in thinking about an open eastern border. Those holding a negative view to free movement dropped $12 \%$ during these four years while those holding a positive view increased $10 \%$.

What these results show is, first, that respondents are generally against completely free movement across the eastern border, and second, that having a more open eastern border tends to make people favor it. Despite this trend in positive thinking about an open eastern border policy, respondents from the 1998 survey chose heightened controls even at the 
cost of harm to the bazaars and markets if their adoption would have led to quicker EU entry. Undertaken about two months after the 1997 law came into effect, this survey asked respondents if "we should adopt the conditions the EU is requiring and put forward the appropriate demands on travelers since it might help us to become a member of the EU more quickly even if doing so would have unfavorable effects on trade at the bazaars and markets." 50\% selected this response while 28\% agreed instead that "we should not adopt the demands requested by the EU since they would be disadvantageous for trade at the bazaars and markets and Poland is still not a member of the EU." A significant 22\% said that it was hard to say (Nowe przepisy 1998: 8). Despite this high percentage, half of the respondents ranked the goal of gaining EU membership higher than the economic dislocation by tightening the border.

While it is indeed difficult to foresee the effects of shifting the Schengen border to Poland's eastern border, two things are clear in the Polish case: (1) requirements of adopting Schengen to join the EU have been the driving force behind tightened eastern border policies; and (2) that such tightening in and of itself goes against the wishes of Polish elites, border residents, and potentially against the general population. When combined with asymmetries in Poles' and Ukrainians' views of one another and the sizeable economic differences on either side of the border, Schengen will not likely improve Polish-Ukrainian relations, while also militating against the broader acceptance of liberal values.

\section{Schengen and the Reunification of a Greater Hungarian Nation}

Hungary's case against the need to tighten borders was even clearer. The implications of adopting stricter border controls did not sit well with the former Hungarian center-right party in power from 1998-2002 and again beginning in 2010 (FIDESZ). The party has secured its electoral base, in part, through a strong focus on cultivating ties with the large numbers of ethnic Hungarians in the near abroad. Their formal separation from Hungary has been a prominent issue in Hungarian politics ever since the 1920 Treaty of Trianon left Hungary with only approximately one third of its former population and territory. Thereafter Hungary became one of the most ethnically homogenous countries in the region. Such homogeneity, however, did not characterize neighboring states such as Romania with 1.7 million Hungarians, Czechoslovakia with approximately 900,000 Hungarians, the Kingdom of Serbs, Croats, and Slovenes (Yugoslavia) with its 550,000 Hungarian minority, and Austria 
with approximately 26,000 Hungarians (Kovrig 2000: 25). Today approximately $43 \%$ of Hungarians live outside of Hungary, with $34.5 \%$ living in the neighboring states of Romania, Slovakia, and the Vojvodina district of Serbia (Dostal 1996: 12-13).

Convinced that ethnic Hungarian immigration would surge prior to the installation of the Schengen border, the Hungarian government passed a bill in the summer of 2001 that not only magnified the salience of Hungarian identity in neighboring states, but also increased tensions in elite-level relations with Slovakia and Romania. With a 92\% majority, the Hungarian parliament approved the so-called 'Status Bill' on June 19, 2001. In force as of January 1, 2002, this legislation grants subsidies to Hungarians abroad for health care, education, culture, and transportation along with an identity card giving them assistance in traveling to and for finding work in Hungary. Though the primary reason for considering the Status Bill was to forestall excessive Hungarian immigration prior to the shift of the Schengen border, Hungarian officials mentioned at least two additional motivations. First, Hungarian Premier Viktor Orban noted a need to increase the labor supply, indicating that only Hungarians would be allowed to fill these positions. On June 7, 2001, for example, Orban stated that the country could take in "up to four million Magyar settlers" [RFE/RL Newsline (8 June 2001)]. Second, Hungarian officials have referred repeatedly to a desire to fulfill a historical obligation to the Hungarian diaspora in the near abroad. As Hungarian Foreign Ministry State Secretary Zsolt Nemeth explained during a visit to Romania, Hungary is "repaying an 80-year old debt" by passing the Status Bill - a clear reference to the Trianon Treaty [RFE/RL Newsline (21 May 2001)]. Speaking more strategically, FIDESZ likely used the law to court two groups of voters: (1) less radical supporters of the far-right Hungarian Justice and Life Party (MIEP) and (2) disillusioned voters from the disintegrated Independent Smallholder's Party (FKGP) (Kingston 2001: 2-3).

Under FIDESZ in particular, Hungary's push to join the EU was framed as a route to undo the forced split with Hungarians in the near abroad through lessening the importance of state borders - again a signal that, for Hungary, the idea of 'joining Europe' can be put to the service of the nation. Zsuzsa Csergó and James Goldgeier explain the reaction of Slovakia and Romania: 
The Hungarian effort to 'virtualize' political borders was highly problematic in an area where neighboring states continued to place strong emphasis on maintaining their territorial sovereignty, which in many cases was newly acquired. The legacies of past relationships between Hungarians and their neighbors - a history of dominance and subordination followed by reversals of fortune - contributed to Romanian and Slovak perceptions that the Status Law was merely a guise for the desire to reincorporate territories and 'imperial' ethnic kin that Hungary had lost through the 1920 Treaty of Trianon. Hungarians are a formerly dominant group in the neighborhood and may be using EU integration to reclaim their earlier position (Csergő and Goldgeier 2005: 8-9).

Repeated references to Trianon alone did not make the Bill controversial for neighboring states. It was the implied institutionalization of positive discrimination according to nationality directed, to a significant degree, by a foreign government associated with regional domination. This point was not lost on Slovak and Romanian officials. Slovak Foreign Minister Eduard Kukan worried aloud that the necessity of differentiating between Hungarians and non-Hungarians might 'introduce discrimination' [RFE/RL Newsline (16 May 2001)]. The Romanian Cabinet went farther by arguing that the Bill is indeed discriminatory and that it encroaches on international law. It also stated that any aspects of the Bill contradicting bilateral treaties between the two states would not be in force "on Romania's sovereign territory" [RFE/RL Newsline (20 June 2001)]. Members of the Greater Romania Party in the Chamber of Deputies, moreover, submitted draft legislation after the Status Bill's passage that would give dual citizenship to all those applying for the Hungarian identity card, thus depriving them of the right to hold public or military office (applicable to all those who hold dual citizenship in Romania).

Though members of the diaspora would not have citizenship status, Prime Minister Viktor Orban's comments from December 2000 certainly imply otherwise. "I hope this Hungarian identity card will say very nicely that the person who possesses this document is a citizen belonging to the Hungarian nation, a nation-citizen, if you like. The person owning this card will be entitled to enjoy preferences or rights stemming from his/her special status... This will create a special legal situation, a special status for them" (Hungary 2001: 21). Prior to even dispersing these benefits, however, a process had to first take shape to determine who possesses Hungarian identity. The Hungarian government's Office for 
Hungarians Beyond Borders indicated that Hungarian identity would be conferred "on the basis of a recommendation by a recommending organization beyond the border [and would include] all those who profess themselves to belong to the Hungarian nation and who declare this in writing and those who can make this statement in Hungarian, that is to say, they [can prove that they] speak in Hungarian..." (Hungary 2001: 21).

Though Hungarians residing in the near abroad tend to exhibit a high degree of national consciousness, the process of determining who is a Hungarian and of then administering the benefits only increased the political salience of nationality differences - a process that would not have been deemed necessary without pressures to tighten borders to the east and south. A 2001 survey of Romanians in Transylvania, in fact, showed that almost half of the respondents thought that rights accorded to ethnic Hungarians were too generous. Many also thought Hungarians living in Romania - particularly in Transylvania - feel greater loyalty to Hungary than to Romania (Kingston 2001: 13). Though suggestive of the Status Law's effects, these results were likely influenced by the specific political circumstances surrounding the poll. Carried out by an institute recently headed by Romania's Public Communications Minister, the results were released at a time when the government had a keen interest in sculpting negative public opinion towards the Status Law (Kingston 2001: 13).

The COE, the OSCE's High Commissioner, and the EU all subsequently issued evaluations of the Status Law, reports that Hungarian elites took seriously. While an October 2001 report from the COE's Venice Commission ruled that no legislation with foreign application could be implemented without involved foreign countries' consent [RFE/RL Newsline (19 October 2001], OSCE High Commissioner Rolf Ekeus's criticism was far more direct in faulting the unilateral nature of the Status Law and its potential to create conflict [RFE/RL Newline (29 October 2001)]. The EU's country report on Hungary released on 13 November was also critical, yet did not go so far as to state that the law runs counter to the acquis [RFE/RL Newsline (14 November 2001)]. In an apparent change of mind over the Venice Commission's report, a draft of a subsequent COE report released in June 2002 harshly criticized the Status Law, recommending that it be replaced by a new law passed only after consultations with neighboring states. This report claims that the Law 
actually violates EU norms such as non-discrimination, good neighborly relations, and respect for sovereignty [RFE/RL Newsline (13 June 2002)]. Clearly, the opportunity to observe the law's effects on interethnic relations changed the COE's view considerably.

Though the Status Law was also FIDESZ's tool to retain power (along with EU pressures to tighten borders), the succeeding socialist-led government did not move immediately to abolish it. Hungary's succeeding Socialist-Party Prime Minister, Peter Medgyessy, in fact appeared no less concerned about the Hungarian diaspora. Like Antall and Orban before him, Medgyessy claimed feeling responsible for 15 million Hungarians, rather than just the 10 million living in Hungary [RFE/RL Newsline (9 May 2002)]. While the Medgyessy government approved an amendment deleting references to a unified Hungarian nation [RFE/RL Newsline (24 June 2003)], its failure to consult neighboring states that would ultimately implement the law did not diminish contention.

Nevertheless, improvements were made in Hungarian-Romanian and Hungarian-Slovak relations over the Status Law. In September 2003, the Romanian and Hungarian Prime Ministers signed a bilateral agreement concerning the Law's implementation. It stipulates two important changes that de-emphasize Hungarian identity. First, Hungarian ID cards can only be issued in Hungary, must not carry the insignia of Greater Hungary, nor can they resemble passports. Second and more importantly, institutions rather than individuals are to be the recipients of financial aid for preserving Hungarian culture [RFE/RL Newsline (24 September 2003)]. A similar agreement was reached between Hungary and Slovakia in December 2003. Such changes have ultimately diminished contention over the Status Law.

Looking ahead to the future, it will be interesting to see how the opportunity for 'Hungarian reunification' affects identity politics. Will the bringing down of borders empower Hungarian minorities and make them less likely to organize as Hungarians (thus often provoking discriminatory responses)? Or will the reality of 'reunification' be perceived as a threat to Romanians and especially to Slovaks; the latter holding still-strong memory of a thousand year existence under Hungarian rule? 


\section{Schengen and the Creation of a 'Europe of the Regions'}

The emergence of the Schengen system has given credence to sub-state regionalism manifested in the idea of creating a 'Europe of the regions.' The practical implementation of this idea in CEE runs from Hungary's efforts to re-unite a greater Hungarian nation to EU support for 'Euroregions.' Euroregions are geographically demarcated areas spanning state borders possessing a very loose institutional structure geared towards furthering collaboration between local governments on either side of the border(s). While the Euroregion projects have been perceived as threats to identity and sovereignty in some states, again for Hungary they harmonize nicely with the Hungarian reunification project. Relating this project to the Status Law, Orban notes:

I am convinced that the [Status Law] contains a number of novelties judging even by European standards and it also outlines a Hungarian concept about the Europe of the future. During the time of de Gaulle, the French thought that the European Union has to be a union of states belonging to Europe. During the time of Chancellor Kohl the Germans came to the conclusion that the Union has to be the Europe of the regions. And now, we Hungarians have come up with the idea that the Europe of the future should be a Europe of communities, the Europe of national communities, and this is what the [Status Law] is all about (quoted in Csergő and Goldgeier 2004: 28).

Hungarian Foreign Minister Janos Martonyi advanced a similar view claiming that while states in the new EU-bounded Europe would retain their role as primary decision-making bodies, Europe's future would essentially be determined by its various communities (Kingston 2001: 8).

Though Hungary's reunification efforts might at times prove unsettling to Romanians, the Romanian elite similarly employed the reunification idea in the context of European integration with respect to Romanians in Moldova and Ukraine. Thus, Romanian Prime Minister Adrian Năstase advanced the idea of the EU as a 'union of nations' (Csergö and Goldgeier 2004: 28), while Romanian President Ion Iliescu claimed that "European borders cannot be changed, but integration into the EU will inevitably relegate the importance of national borders." Illiescu added that "Romania supports the integration of the Republic of Moldova and Ukraine into European structures. Bucharest wanted to preserve the cultural and linguistic unity of Romanians all over the world" (quoted in 
Kingston 2001: 8). Yet, Hungary has pursued transovereign nationalism with greater vigor given two factors: (1) far more ethnically homogeneous Hungary has little to fear from similar campaigns coming from other states than multiethnic Romania, and (2) nation- and statebuilding began considerably earlier in Hungary, leaving ethnic Hungarians in the near abroad with a stronger sense of Hungarian identity (Csergő and Goldgeier 2005: 15). Though appealing to nationalities wanting to reunite a nation spilling well over state borders, the creation of a Europe of the regions can also be threatening in two related instances: (1) in states with border areas that recently experienced border shifts and/or population expulsions, and (2) in border areas of weak states, ones that are fragmented given higher degrees of ethnic diversity. Both the Czech-German and Polish-German borders are excellent examples of the former given their repeated shifts in the $20^{\text {th }}$ century and large-scale German expulsions. Both also have shown some concern over the development of Euroregions spanning these border regions as being part and parcel of increased German power. Czech and Polish opponents of Euroregions have claimed that they are a mechanism promoted by Germany to further economic expansion in the region (Bazin 2003: 227). While Czech Prime Minister Vaclav Klaus characteristically claimed the Euroregions as a potential threat to identity, his Polish counterparts questioned whether they would lead to the dismemberment of the Polish state itself. After voting on the creation of the Carpathian Euroregion spanning the Polish, Ukrainian, and Slovak borders in 1993, the Sejm produced an official statement claiming "Euroregions cannot become a means of denying the sovereign power of Poland over parts of her territory" (quoted in Malendowski 2000: 22).

The second situation when creating a 'Europe of the regions' appears threatening concerns border areas of weak, fragmented states, states not holding significant power and legitimacy over a diverse population. Judy Batt makes this point when discussing the effect of European integration on two of CEE's historic subregions that lie largely on the other side of the new Schengen border: (1) the Banat - encompassing the two counties in southeast Romania, and (2) Transcarpathia - the westernmost region of Ukraine. Both have developed historically as regions despite border changes and population movements occurring in the $20^{\text {th }}$ century. Given their relative western location and greater identification with Europe, elites there have adopted the 'Central European argument' to claim that these areas are more civilized and ultimately culturally 
superior to the more 'barbaric' Russian-controlled areas to the East (Batt 2002: 507-508).

This sense of uniqueness along with EU efforts to support the development of border regions (even cutting across the Schengen border) has created a sense of insecurity among the Romanian and Ukrainian elite. Though Romanians like Năstase and Iliescu might support the idea of a 'Europe of the regions' to forge closer ties with Romanians in Ukraine and Moldova, the same idea can be unsettling in regards to Hungarians in Hungary 'reuniting' with Hungarians in Transylvania - the by product of FIDESZ's own pursuit of crossborder Hungarian reunification.

Ukrainian elites had similar concerns when debating the new constitution. Passed in 1996, it continued with the existing system of oblasti and claimed that Ukraine's territorial structure would be based on "the principle of centralization and decentralization in the exercise of state power" (Article 132 quoted in Batt 2002: 518). As Judy Batt points out, this sentence obscures a rather disorganized reality, one that former President Kuchma used to justify defacto centralization. According to Kuchma: "Practically [today] nobody rules Ukraine. [At the regional level] everybody is interested in his own welfare. The interests of the people and the practical issues of running the state are pushed to the side. These are the first signs of disintegration of the state... We have to eliminate such manifestations of contemporary local feudalism, take radical measures to restore order, [and] protect our citizens" (quoted in Batt 2002: 518-519). Kiev was indeed paying attention to demands for autonomy coming from the areas with strong regional identities and with the longest ties to other states (Batt 2002: 518). While the idea of creating a 'Europe of the regions' appears appealing to Hungarian and Romanian elites when thinking of ties with large numbers of 'kin' in the near abroad, the same idea can also appear threatening to (weak) states with border areas that have also experienced border shifts and/or forced population movements.

\section{Conclusion}

While instituted in the name of liberalizing the Single Market, the continuing development of the Schengen system contradicts the liberal, identity-blind ideology behind the Market. After showing that Schengen was ultimately the product of another time and place and that the 
system's implementation only furthers ethnic hierarchies, this article explains why the idea of creating a 'Europe of the regions' can suggest a destabilizing balance of power among Europe's less historically secure nationalities. By helping Hungarian elites in particular to pursue the 'reunification' of their nation, in fact, this project can be interpreted as a threat to neighboring states with large numbers of Hungarians. Ultimately, Schengen's inadvertent support for a Europe of the regions, its fortification of ethnic hierarchies, not to mention tightening borders along the new eastern Schengen border, only militates against the broader acceptance of liberal values.

\section{References}

Bachmann, Klaus. "Marnowane Szanse Dialogu" [The Chance for Dialogue Wasted].

Rzeczpospolita, 22 November 1994.

in the Schengen "Nie Wiercić Dziur w Systemie Schengen“ [Don't Drill Holes System]. Rzeczpospolita, 9 August 2000.

Batt, Judy. "Between a Rock and a Hard Place -- Multi-ethnic Regions on the EU's New

Eastern Frontier.” East European Politics and Societies 15(3): 2002.

Bazin, Anne. "Germany and the Enlargement of the European Union to the Czech Republic." In

The Road to European Union, Vol. 1. Ed. Jacques Rupnik and Jan Zielonka, Manchester: Manchester University Press, 2003.

Bielecki, Jędzej. "Zadania na Najbliższe Lata" [Tasks for the Next Few Years]. Rzeczpospolita,

5 February 1998a.

"Trzeba Jakoś Żyć [You Have to Live Somehow]. Rzeczpospolita, 6 February 1988b.

Bort, Eberhard. "Grenzen und Grenzräume in Mitteleuropa" [Borders and BorderAreas in

Central Europe]. WeltTrends 22: 1999.

Csergő, Zsuzsa and James M. Goldgeier. "Nationalist Strategies and European Integration."

Perspectives on Politics 2(1): 2004.

Dostal, Ondrej. "Wspólny Problem" [A Shared Problem]. Gazeta Wyborcza, 3/4 August 1996.

"Gęstsze Sito na Granicach" [The Dense Sieve at the Borders]. Rzeczpospolita, 9, January 1998. 
Goodman, John B. and Louis W. Pauly. "The Obsolescence of Capital Controls? Economic

Management in an Age of Global Makets." World Politics 46: 1993.

Grabbe, Heather. "The Sharp Edges of Europe: Extending Schengen Eastwards." International

Affairs 76 (2): 2000.

"Hungary." East European Constitutional Review 10 (4): 2001.

Janecki, Stanisław and Piotr Cywiński. "Czarny Charakter Europy" [The Dark Character of

Europe]. Wprost, 26 March 1995.

Kingston, Klara. "The Hungarian Status Law. RFE/RL East European Perspectives 3 (17):

2001.

Kovrig, Bennett. "Partitioned Nation: Hungarian Minorities in Central Europe. In The New

European Diasporas: National Minorities and Conflict in Eastern Europe. Ed. Michael Mandelbaum, 19-80. New York: Council on Foreign Relations, 2000.

Kurcz, Zbiegniew. "Pomysły na Pogranicze Polsko-Niemieckie" [Thoughts on the Polish-

German Border Area]. Odra 11 (374): 1992.

Lavenex, Sandra. Safe Third Countries: Extending the EU Asylum and Immigration Policies to

Central and Eastern Europe. Budapest: Central European University Press, 1999.

Lisiecki, Stanislaw. "Otwarta Granica: Przemiany w Świadomości Mieszkańców Pogranicza”

[The Opening of the Border: Changes in the Consciousness of Border Residents]. In

Otwarta Granica: Raport z Badan na Pograniczu Polsko-Niemieckim 1991-1993 [The Open Border: A Report on Research Concerning the Polish-German Border Area 1991-1993]. Ed. Stanisław Lisiecki, 287309. Poznan: Instytut Zachodni, 1995.

Malendowski, Włodzimierz. "Euroregiony a Suwerenność Państwa" [Euroregions and State

Sovereignty]. In Euroregiony: Mosty do Europy bez Granic [Euroregions: Bridges to a Borderless Europe. Ed. Włodzimierz Malendowski and Marian Szczepaniak, 19-33. Warsaw: Dom Wydawniczy ELIPSA, 2000. 
Menasse, Eva. "An Europas Staustufe" [At the Locks of Europe]. Frankfurter Allgemeine, 30

May 1998.

"Nowe Przepisy o Ruchu Granicznym - Pierwsze Reakcje i Oceny" [New Rules on Border

Traffic - First Reactions and Views]. Survey \#33 (N=1167). Warsaw: CBOS, 1998.

"Opinie o Niemcach, Republice Federalnej Niemiec i Stosunkach PolskoZachodnioniemieckich" [Opinions on Germans, the Federal Republic of Germany, and on Poland's Relations with West Germany]. Survey \#431 (N=1498). Warsaw: CBOS, 1989.

Pawlicki, Jacek. "Polska Granica Europy" [Poland, the Border of Europe]. Gazeta Wyborcza,

21 February 2002.

Peterlik, Marcin and Bohdan Wyżnikiewicz. "Zmierzch Wielkich Bazarów" [The Twighlight of

the Great Bazarów]. Rzeczpospolita, 1 June 2000.

"Polacy o Możliwości Pojednania z Niemcami i Ukrainą" [Poles on the Possibility of

Reconciliation with the Germans and with Ukraine]. Survey \#100 (N=1092). Warsaw: CBOS, 1999.

Sadurski, Wojciech. "Obniżyć Nowy Mur Berliński” [To Lower the New Berlin Wall].

Rzeczpospolita, 13 February 2002.

Scharpf, Fritz. Governing in Europe: Effective and Democratic? New York and Oxford:

Oxford University Press, 1999.

"Tak Blisko, a Tak Daleko" [So Close and Yet So Far]. Gazeta Wyborcza, 21 November 2001.

Taschner, Hans Claudius. Schengen. Baden-Baden: Nomos Verlagsgesellschaft, 1997.

"Ukraine, Poland, and the EU's Wider Europe Initiative." RFE/RL Poland, Belarus, and Ukraine

Report 5(25), 1 July 2003.

"Wschodnia Granica Polski Granicą Unii Europejskiej - Przewidywane Skutki Zmian" [Poland's

Eastern Border as the EU Border - Predicted Effects]. Survey \#129 $(\mathrm{N}=1050)$. Warsaw: CBOS, 1998.

Zagrodzka, Danuta. "Na Górze Róze, Na Dole... Pokrzywy" [Roses on Top, Thorns on the Bottom]. Gazeta Wyborcza, 26 June 1997. 